\title{
Beyond Entanglement
}

\section{Christina Fredengren}

This keynote discusses how human-animal relationships can be studied as entanglements to understand more of the situatedness of human and animal bodies and lives. It provides a selection of thinking tools from critical posthumanist feminism and new materialism which should prove useful for studying more-than-human worldmaking through archaeology. These tools can be used to study how humanity and animality are produced, how to recognise animal agentiality, and to highlight challenges on the way. Key issues are identified in concepts such as taxonomies, hybridity, othering and killability. Examples are drawn from recently published research on human-animal relations in archaeology on rock art, depositions, sacrifices, burial practices and more. The paper also tests how speculative methods can be a way of approaching more-than-human exposedness, situatedness and agentiality. It makes an argument that while it is important to study the entanglement of bodies as material-semiotic phenomena, it is of equal importance to also address questions on inequalities and injustices, and who carries the burden in particular situated entanglements and thereby move beyond the study of entanglement on its own.

Keywords: human-animal relations, critical feminist posthumanism, nature/culture, water, wetlands, depositions, sacrifice, killability, bybridity

Department of Archaeology and Classical Studies, Stockholm University

christina.fredengren@arklab.su.se 


\section{Tying knots with the more-than-human}

This keynote is centred on how to forward the study of the more-thanhuman world through the archaeological record. The aim is to carry out academic work that is both affirmative and critical: affirmative as it invites to analytical creativity and academic generosity; and critical in so far as it calls into question power differentials.

I will present some thinking tools that can be used to address questions about the changing relationships and framings of the human, non-human and the more-than-human. I hope that this might inspire further work on how humans and animals may have contributed to situated intertwined worlds. Such tools can be used to explore how relations between species have been knotted together differently in the past, but also how such relations may be tied elsewise and transform over time. It will not be argued that my take is the only way forward; there are many paths that can be chosen with valid results. However, the choice of tools can expose other parts of reality that have not been given as much attention in research, such as how situated worlds are made together with animals, but also how such making favours the thriving of certain beings at the expense of others.

In particular, I make use of critical feminist posthumanism, with roots in new materialism, in order to discuss how the world is co-produced by humans and animals and how relations between humans and animals are tied together in situated ways - both temporally and spatially. Karen Barad (2007:32) uses the term posthumanism as 'a refusal to take the distinction between "human" and "nonhuman" for granted, and to found analyses on this presumably fixed and inherent set of categories'. This also has bearing in an ongoing questioning of normalized boundaries between entities and species (Haraway 2004:8) and to discussions on the recognition of animal agency (Despret 20I3). Based on this reasoning, a separation into species cannot be taken as an absolute; instead animality or humanity are worked on and produced. Such distinctions may vary over time and situation and hence are a question for archaeological and historical studies to trace and investigate. It is important to see where boundaries are drawn at different times and how categories form. However, as both Haraway \& Barad would underline, bodies are not primarily social constructs in people's minds, but come together as situated complex material-semiotic entanglements. This means that there are several material, relational and also ethical (Barad 2007) processes at work that produce lived, material bodies.

Several archaeological studies, be they inspired by for example Science and Technology Studies (e.g. Latour 1993) or by the feminist thinkers above, have worked with the analytical tool of entanglement, related also to the study of assemblage. This tool has broadly been used to capture human rela- 
tionships with for example things (see Hodder 201 2, 20I6; Der \& Ferrandini 20I6; Marshall \& Alberti 20I4; Fowler \&Harris; Jones 20I5) and how such relationships may have brought specific facilities, dependencies and other set-ups into place. While there are gains in moving from categorical to such relational approaches, there is also a need to move beyond the much-used entanglement concept and method in analysis. I will make the point that such work has to take a step further and look at power relations and practices of care and mutualism, but also of domination, oppression and exploitation that shape relations between humans, animals and nature. Based on a discussion of posthumanism, taxonomies and hybridity, I will articulate the importance of looking at othering in order to recognize injustices and the production of the inhumane. This will be exemplified by research in the ongoing Water of the Times project that deals with changing human-animal relations as evidenced in depositions of human and animal bodies in Scandinavian wetlands. I end with a discussion on what a non-anthropocentric multi-species archaeology could be like and where I see productive future meeting points between archaeology, critical feminist posthumanism and human-animal studies - which in turn might influence directions in subjects such as archaeology, museology, heritage, gender studies and the environmental humanities.

\section{Human-animal studies}

Cary Wolfe (2009:564), a founding figure in critical animal studies, writes 'that "the animal", when you think about it, is everywhere' and this holds true also for the archaeological record. Archaeology presents a number of both traditional and innovative paths into human-animal studies, not the least through their representation in art and early literature (Bintley $\&$ Williams eds 2015), zooarchaeology (Overton \& Hamiliakis 20I3; Storå et al. 2020), zoosemiotics (Armstrong Oma 2020), and approaches that use natural science methods (e.g. Glykou et al. 202 I; Nyström et al. 20IO) to understand both food ecologies and the extinction of animal species.

Countless archaeological studies form the classic fields of research into hunting, warfare, animal domestication and breeding (e.g. Childe ([I928]I954); Gamble I985; Pluskowski 2007; Jordan 2004; Dobat et al. 20I5; Overton \& Taylor 20I 8), and how animals are used as food resources (Fjellström 2020) or as sacrifices (Kaliff \& Oestigaard 2020). Animals also make themselves known in settlements, infields, outfields and other uses of the landscape (Pedersen \& Widgren 20II; Costello 2020). Animals (and mixes between humans and animals) are widely represented in art (e.g. Arwidsson 1942; Hedeager 2010, 20II; Anderson in press) and work as 
symbols and figures of thought (e.g. Kristoffersen 20Io; Ahlqvist \& Vandkilde 20I 8). Indeed animals permeate archaeological material; their bodies stretch tentacularly through material culture. Consider the use of feathers, wool, skin or bone materials that are made into products for humans, (Karlsson 2015; Bergerbrant 2019; Mannermaa \& Kirkinen 2020), where animal body parts are plaited into craft and trade networks and thus braid into for example both species and gender relations.

Animals have recently taken a more prominent place in archaeology as in other disciplines as part of the research focus known as the 'animal turn'. Here classifications and the changing values attributed to animal species come into focus (e.g. Jennbert 20I4). Tracings of the entanglements of humans and animals are central here, as seen in Kristin Armstrong Oma's work on 'the sheep people' (20I8), Joakim Goldhahn's (2019, 2020) research into birds in the Bronze Age, and Fredrik Fahlander's (2019) study of animal-boat hybrid rock-art. My own transcorporeal studies into how human and animal bodies are materially co-produced with their situated environment, as evidenced in for example bone isotope analysis, are another example of such entanglements (Fredengren 20I3, 20I8a). Within this new frame, studies on paleodiet have thrown light on human-dog relations and provide situated cases for intra-species food-sharing (Harris 2020). Multispecies archaeology has even made it into foundational curriculum books (e.g. Harris \& Ciapolla 20I7). Following this path, the themed papers collected in last year's edition of Current Swedish Archaeology used a variety of materials to work with 'multispecies intra-actions in a long-term perspective', focusing on how human-animal relations are tied (Armstrong Oma \& Goldhahn 2020). In recent years animals have been studied as more than how they are represented in the human mind and increasingly matters of entanglements are in focus (e.g. Armstrong Oma \& Hedeager 20I0; Pilaar Birch ed. 20I8). I fully support work that traces out the multiple sources that braid together bodies, but I also see that such approaches can be brought one step forward to deal to a larger degree with the effects of such lives that are differently situated in such entanglements.

\section{Entanglement and beyond}

Entanglement has been an immensely productive concept in human animal studies as a counter to human exceptionalism and as a tool for interrogating relational complexity in material body formation. For example, key thinker in the field Donna Haraway (2008) counters anthropocentrism with the statement 'We have never been human' (Haraway 2008:I-3) and points out that only Io percent of the human body contains human ge- 
nomes, while 90 percent is filled with genomes from fungi, bacteria and micro-organisms. Furthermore, Haraway states 'To be one is to become with many' (Haraway 2008:4). Hence, both human and animal bodies are situated and entangled knottings of several more-than-human contributors. This theoretical lens lets human-animal entanglement come to the fore in critical animal studies.

As exemplified above, relationality and entanglement have also been entry points for several recent archaeological studies of human-animal relations and beyond. However, such entanglements were arguably also dealt with in earlier archaeological studies, albeit not framed as such. One example is Gordon Childe's ([I928]1954:25) discussion of domestication:

In any case, the conditions of incipient desiccation at which we have hinted would provide a stimulus towards the adoption of a food-producing economy. Enforced concentration by the banks of streams and shrinking springs would entail a more intensive search for means of nourishment. Animals and men would be herded together in oases that were becoming increasingly isolated by desert tracts. Such enforced juxtaposition might promote that sort of symbiosis between man and beast implied in the word 'domestication'.

At this stage domestication was already described as a symbiosis between humans and animals, where all involved in the game changed and became something else by entering the alliance. Haraway (2016: chapter 3) furthers her argument by highlighting the evolutionary role of sympoesis, 'the making with', which can be compared to the study of autopoesis, in which something bounded replicates itself. To study entanglement means to trace how the world comes together as materialising process in which several sources and forces join up. I would together with Haraway make a point in that not only humans contribute to developments such as domestication. Also, other actors such as animals need to be acknowledged as co-workers and co-producers of reality and it is important that the morethan-humans (be they micro-organisms, cattle or dogs) are given recognition in history writing.

This connects to the problem of how to recognize animal agency. Kristina Jennbert (20I4:I9I) urges us to 'develop a non-anthropocentric approach to agency in order to consider different attitudes and values concerning humans and animals'. However, it is not always clear how animal agency can be approached in practice; there is a risk that archaeological studies which set out to study relations with animals end up centring the human anyway. Historian Erica Fudge (20I7) has pointed out, there is a historiographical problem of how to find methods to detect animal agency and emotionality, and how to learn from being with animals, and this is a challenge also to archaeology. 
As philosopher Vinciane Despret (2013:29) explains, taking an animal's perspective or exploring its ways of accessing the world may or may not lead to a recognition of its agency. One needs both to acknowledge the contributions of animal agency and also to look at other types of agency - and this may entail moving beyond working with agency as 'intentional, rational, and premeditated' (Despret 20I3:33), which is important also for how to write animals back into archaeological narratives. The presumed 'rational man' as a measure stick for humans and animals alike is thus displaced as a model for more-than-human agency. Instead Despret (20I3:38) proposes a focus on 'agencement' as a process of attunement that is also brought about through several sources and forces that make 'some beings capable of making other beings capable' (Despret 20I3:38). Such gatherings are shared extensively in the world of the living between a variety of agents. They can be investigated in situated webbings that both coincide in and stretch out to and from a particular body.

A further alertness applies to the 'narrative-economies' subscribed to in descriptions of animals, and here again there is relevance to archaeology. Some narratives are built up around ascribing animal behaviour as simply reactive to stimuli, or the view that the animals rationalize and maximize food intake or their reproductive possibilities, or explaining behaviour in terms as competition, deception or exploitation (Despret 20I3:34). Instead there must be room for other narratives around animal agency, for example ones that come about in playfulness, through pleasure and through the attunement of animals to several material and immaterial forces.

One approach is to search in the material for evidence that brings animal action to the forefront of analysis (Despret 2013:35). This may also imply methods that directly involve researchers in affective relations with more-than-human others. An example can be found in Armstrong Oma's (2020) discussions on the work of sheep-dogs, where the dogs also have to be in tune with sheep in order to take decisions about their joint movements. The world can then be analysed as containing 'beings able to affect and be affected by others' that in turn are involved in each other's lives (Despret 20I3:35-36) and as coming into being not only by human to animal contact, but also in animal to animal intra-action. Despret (20I3) thus analyses a world in which everything acts and participates in the ongoing processes and contestations of situated world makings. In this reasoning, more-than-animal others are endowed with agentiality, but also in the exercise of meaning-making and power formation.

Human-animal entanglements can be traced through archaeological material in numerous ways. One way is to trace digestive ecologies in stable isotope analysis as they intermesh with the corporeal, or the mixed genetics that work across human and animal bodies, or how humans and animals 
carry out transformative joint attunement when they live and work together. But as anthropologist Deborah Rose (20I1:IO-I 2, I 47) points out, the earth and its relations are always works-in-progress that produce situated worlds, where different possibilities for life and death are brought about. To work with such worldmakings or worldings in archaeology would mean tracing material-semiotic-ethical entanglements (see Barad 2007) in situated places in ways that do not place the human in the centre and which acknowledge multispecies agencies and the possibilities they generate.

However, I would emphasize together with both Rose (20II) and Eva Girard (2019) that it is not enough to unpack the entanglement of bodies (and things) and leave the analysis at the level of providing a rich description of the complex relationality of situated world makings. Rather there is a need to continue a step further in the archaeological analysis, to look at who carries the heaviest burden in time- and site-specific entanglements, and thus what is tended to and what is excluded from benevolence and care. We need to bring with us knowledge gained through relational approaches, but also to move beyond entanglement to start to discuss power, tensions and dilemmas as working through and between bodies. Such an approach gives rise to questions inspired by Rose (2OII:II-I2): what sort of worlds come into being in particular situated places? To what extent is mutuality between species sustained or altered? How do the possibilities for life develop and who flourishes in particular settings? What thrives (or does not thrive) in specific conditions? To examine worlding in this way means to trace how a range of different living beings contribute to the making and unmaking of worlds and to ask the question, cui bono?

In my own studies on human-animal-nature relations manifested in sacrifice and depositions in water, I try to trace several underlying processes of how the world came into being in situated ways and what effects this may have had (Fredengren in press, manuscript). I want to build a denser understanding of the historical and archaeological circumstances that recognizes both the care and maintenance work that takes place, but that also consider that some 'othered' participants lost their lives for others to thrive.

\section{From categorical to relational methods}

Categorization is a common technique of othering. The separation of animals as a category distinctly different from humans has been problematized by many thinkers (e.g. Barad 2007; Haraway 2008; Braidotti 20I3). Let us look at some common categories used, such as human and non-human animal. This language device emphasizes how these two categories are contained within the general fold of the animal. However, while join- 
ing up at a meta-level, such a description also creates a binary at the lower level as it bifurcates humans and animals. Compared to the terminology buman and non-human animal, the language tool more-than-buman can be used to acknowledge the relational multiplicities of humans, animals and things. Animals come about as situated knottings of genes, technology, practices, habitats and so forth that stretch out and link up beyond and in excess of what is labelled human or animal. This is what Haraway (2008:88) means by pointing out that 'individual animals, human and nonhuman, are themselves entangled assemblages of relatings knotted at many scales and times with other assemblages, organic and not'. Hence, animals are always more-than-animals, humans- more-than-human as they come together and change as situated material-semiotic and also ethical entanglements.

However, taxonomies and scientific naming present the researcher with a dilemma, as such practices are ways of stilling an evolving and interconnected world for study. Some bits of the world are held apart to be observed and captured by apparatuses of different kinds (whether theories, words or measuring machines). This is what Barad (2007:38I) describes as the making of agential cuts: processes through which parts of the world are both set aside, and at the same time joined up and produced as a phenomenon. In such processes, calling a species or specimen by name also means that parts of a particular being's materialising entanglements are highlighted, while others are disregarded. Scientific observation lifts out pleated bits of the world and affects both its future material and immaterial developments. However, as Alaimo \& Hekman (2008:6-7) writes, this material feminism moves beyond linguistic explanations, to acknowledge how matter 'matters'. However, this does not mean that human-made distinctions are void of material effects and that it is only humans that carry out differentiating work. Distinctions drawn along gender, class or species lines can work othering, and importantly, have material effects, as such categorisation from time to time structures access to resources such as food, shelter and care. Furthermore, bodies are networks full of tensions and dilemmas, where some beings and their networks flourish at the expense of others (see Fredengren 20I8b, manuscript).

The move from categorical study of animals to a relational study of entanglement involves several shifts. One move is to problematise categorisations that may be taken for granted. This involves asking questions about how the boundaries between humans and animals have been drawn over time, and this is an important task for archaeological studies. As Tobias Lindström (2020:153) demonstrates in case studies from the Scandinavian prehistoric Pitted Ware Culture, boundaries now regarded as stable may be contingent: he shows that in death humans and animals were treated in similar ways with regard to splitting of bones and exposure to fire suggest- 
ing humans did not draw a clear border between the two. Another example of such separation, or joining up, is when humans and animal either shared living spaces or were separated out to maintain hygiene boundaries in marked out dwelling spaces (e.g. Armstrong Oma 2020:I I4).

Another move involves examining how human and animal bodies and the environment come together and entangle in spatially and temporally situated ways. Armstrong Oma (2020:I00), for example, explores intra-action with sheep-dogs as hybrid creatures and mediators in human and sheep affairs. In the Water of the Times project, both bones classified as human and as animals were studied in order to investigate the entangled relations that made these situated bodies come into place and change (see Fredengren 20I3, 20I5, 20I8a, 20I8b). Here, Stacey Alaimos' (20I0:2) reasoning on the transcorporeal provided an important tool for studying how materials transits between and together with other bodies. This meant making use of both osteo-archaeological and biomolecular methods to trace how particular bodies were materially and semiotically produced. Stable isotope analysis in particular shows that the coming together of a human body is in fact always more-than-human, as food intake also composes a digestive landscape at work within the body - as a landscape within (Fredengren 2013). Furthermore, the transcorporeal tool has also been used to examine the joint bodily movement and the necessary tuning in of humans and animals that move on the hoof through the landscape. Such trans-species movements may have highlighted particular wading places in the landscape, that over time became depositional places for human and animal remains (Fredengren \& Löfquist 2015).

In a critique of fixed taxonomies Haraway (2004:70) directs hope to studies of the 'inappropriate/d other'. Such studies focus on lives that fall out of common-place categories, to engage in encounters with unruly existences out of bounds. Certain beings have the potential to produce a critical, diffractive relationality with the power and challenge standard taxonomies and semantic appropriation, as they may make visible potent links and existent excesses that surpass and leak outside dominant language and narratives. This means they could work as glitches in the system that let other parts of reality show, dislocated from normative maps and taxon.

\section{Hybridities and monsters}

Haraway (2004:66) has taken a particular interest in border-creatures such as cyborgs and even monsters, as such beings slip out of taxonomic folds. They highlight hegemonic boundaries of discourses and at the same time hold the promise of other ways of understanding workings and worldings 
of the world. But importantly such studies are also important for scrutinizing taxonomic envelopes as active tools of othering. In this lie the 'promises of monsters, the first invites the illusion of essential, fixed position, while the second trains us to more subtle vision' (Haraway 2004:70) as we 'have to get inside all the excessive connections and unruly categories in order to make sense at all' (Haraway 2004:4). One example is Erica Fudge's (2002:9I-98) work on early modern bestiaries. This has exposed not only the history of a developing anthropocentrism, but also how some of these works explored fantastic animals that definitely would not fit into modern categories, such as unicorns, werewolves and demons. Fudge also explores how the human at this stage was a rather unstable category, one that demanded a lot of struggle to be kept together (Fudge 2002:9).

The idea of human-animal hybrids and boundary-crossing between species as widespread and powerful in mythology and magical practices across the human past goes back to the earliest ethnography and folkloric studies. Such species boundary blurring has been discussed by Lotte Hedeager (2004:234) as people during the Iron Age living in a world where they expected 'transcendental' creatures to appear. Hybridities and fantastic beasts abound in storytelling from the past of north-western Europe, as exemplified in Norse mythology, the Icelandic sagas and Irish medieval landscape poems (see Hedeager 2004; Fredengren 2018c; Merkelbach \& Knight eds 2020). One example is how an Irish landscape poem mentions that a treasure was deposited in a lake together with the body of a 'werewolf man' (Fredengren 20I8c). There is also material culture that can be interpreted as having a role in bringing such hybridity into place. I have discussed finds of for example horned head-decorations from watery places (as the Runnabehy horns or the Derrymaquirk bog body deposited with antler tines found at Lough Gara, Ireland), as implying practices in which people in the Early Iron Age may either have worked animals into fantasy creatures such as horses with horns, or where people were dressed up as animals, hybridising and becoming animals. Furthermore, depositions of human and animal remains in watery places may have been important in the production of such beings (Fredengren 2002:195-I98 and references, 20II and references; for related reasoning applied to Mesolithic material, see Conneller 2004). Similarly, Anne Monikander (2010) highlights how wetlands may have been associated with border creatures and the hybrid motifs of bracteates (see also Kristoffersen 20I0). Moreover, there are features in Bronze Age Scandinavian rock art which have been taken as indicators of such hybrid phenomena (e.g. Ahlqvist \& Vandkilde 20I8; Kveiborg et al. 2020). Fredrik Fahlander (2019), for example, understands rock-art boats with animal heads as hybrid and fantastic beings. Hence there is plentiful evidence from both written sources and archaeology to suggest that neither 
human, nor animal were at all times stable categories in these places. On the contrary, they may have been composed both materially and conceptually as fleeting occurrences.

While the out of category problem has been well-investigated in the field of archaeology, where that which is classified as ritual often, with postenlightenment rationalism, is distinguished as out of bounds from that perceived as functional or personal (see Brück 1999, 2004). As argued here, there is also an out-of-category problem in the study of human-animal relations that needs attention. The many examples of hybridity suggest an instability of human-animal-environmental categories during parts of the past. Possibly, archaeological evidence for hybridity could be connected to attunements to a reality where several agencies were given recognition for their lively contributions making situated worlds to come into place.

However, following on from posthumanist thinking about hybridity, it is important to note that while bodies are material get-togethers that cross over human-animal-nature boundaries, they are constantly on the move. Hence, there are no pure, essential bodies to be had in the first place. Therefore, there can be no such thing as an untainted non-hybrid either, as bodies are collections of several situated material and immaterial relations.

One problem with hybridization is that it may work as a firming-up of binaries, when it is based on the existence of two essential categories that eventually blend, whether the human and non-human, or nature and culture. The hybrid may hence have a bifurcating effect, that of essentialization, including in the past. The sacrifice of a werewolf, for example, can be built on the construction of a pure category of human and a pure category of wolf, both acceptable in their places, but where the mixed existence was othered and may have fallen out of the category that receives care and protection, but rather is to be excluded and exterminated. The challenge is to see how bodies historically emerge and change as networks that at different paces are on the move to something else - but also to keep an eye out for when both categorization, including into hybridity, is works for othering and thus subjugation. At the same time as bodies are materialising phenomena that come together through the agentialities of several sources and forces, taxonomies can have real, material effects as they may manoeuvre bodies into life and death.

\section{Killability}

The term 'human' can itself be analysed as a power move that lets only a select few inside its bounds, and that in the same move deprivileges others. As Rosi Braidotti (2013:I) writes: 
Not all of us can say, with any degree of certainty, that we have always been human, or that we are only that. Some of us are not even considered fully human now, let alone at previous moments of Western social, political and scientific history.

Braidotti (20I3:8I) further notes that the feminine 'never quite made it into full humanity' and hence the category 'human' is a privilege only for a select few (as also have been dealt with in postcolonial studies). She underpins her critical argument with an exposé on how the category human mainly applies to those creatures that fall inside categories as for example land owners, holders of citizenship or rights and hence excludes several humans that exists outside these bounds (Braidotti 20I3:I and references). Furthermore, the Cartesian dictum 'I think, therefore I am' or Kant's community of reasonable beings (Braidotti 2013:I and references) moves several others, such as animals, into a category of mindless creatures. As Brian Boyd (20I7:300) adds, anthropocentrism is also an ethical position where humans have intrinsic value and where animals have economic and symbolic value to humans.

A major relationship between humans and animals is acted out in violence and killing practices - as animals have economic value and are used as food or in the making of things for humans. Furthermore, their lives and bodies are made use of in sacrifices. In particular, the trope of sacrifice is installed in many processes around us, which makes it especially important to investigate and clarify who and what is made expendable at different times. For example, humans, animals and environments are sacrificed for developments of other necessities, such as resource extraction and economic growth. The Water of the Times project studies how sacrifice and othering may have transformed the relationships between human-animalnature(s) and worked to shift historically set up boundaries and relations between self and other, but also produced death (see Fredengren 20I8a, $\mathrm{b}, \mathrm{c}$, in press). In this ongoing work, I problematize matters around necropolitics and the killability of humans and animals, as evidenced in the deposition of bodies in watery places. I draw on Braidotti's (2013) and Achille Mbembe's (2003) work and critique of Agamben's conceptions of sacrifices as tied to 'Homo sacer' (see Braidotti 20I3; Fredengren \& Löfqvist 20I9).

Haraway (2008:77-78) has reflected on the notion that while animals are killed, only humans can be murdered, which is grounded in a belief that while animals only react, humans respond. This is a rhetoric that has been used also in mass-murder of human who have fallen outside the bounds of being acknowledged as fully humans, as if their lives and deaths did not matter. Derrida figured that such arguments around killing are based on statements that certain beings are acknowledged as capable of giving a re- 
sponse, and that this is one of the major tools that produces a division between certain humans and other humans and animals, which also open up for sacrificial action (Derrida 2008:25; Haraway 2008:77). However, Haraway adds 'It is not killing that gets us into exterminism, but making beings killable' (Haraway 2008:80). It is important to trace and recognize a variety of practices as well as material and immaterial conditions that lead up to certain lives being were made killable and thereby possibly exposed to asymmetrical suffering and death.

That leads to the questions that I work with in the Water of the Times project. My case studies have dealt with the shifting phenomena of sacrifice and the production of killability, thereby covering long periods of time, through the Scandinavian Bronze and Iron Ages. It is clear that sacrifice can work for othering, and the overall results from Water of the Times are that there are both local and temporal differences as to whom is singled out for killing and/or for deposition in waters. In certain places and times species distinction mattered and during other times gender distinctions mattered in the production of killability, but there are also several other processes that moved certain bodies into life and others into death.

One case study - that around Uppåkra in Skåne, Sweden (Fredengren $2018 \mathrm{~b}$ ) - showed that there was a sex/age bias in the human bodies deposited in wetlands - where body parts defined as from adult males were in focus. The Uppåkra examples supplied a tracing of the bodily history of those deposited in wetlands. A number of these bodies seem to have been produced by neglect and an active exclusion from networks of care throughout their life-course, as evidenced in signs of cribra orbitalia and other skeletal indicators of poor condition. Many of these bodies showed signs of malnutrition - as if these sacrifices started to be produced long before the actual death of the bodies. Possibly, through poverty and lack of access to nutrition, or even lack of nourishment due to crop failure or unequal access to resources, they were made killable. Hence, one can say that such processes could have led to certain bodies being sacrificed already when alive, as they fell outside networks of care. The bodies were not only chosen, but also produced through othering earlier on in life. This may have been a part of processes that eventually also separated these bodies out from those that received a more common burial on land. A question is - were they recognized as fully human during this process or had they been pushed out of that category into that of a less-than-human animal? These depositions of bodies have been radiocarbon-dated to the Late Bronze Age/Early Iron Age and may had a role in the preparation and making of Uppåkra as a prosperous central place in the Iron Age.

Another example is from Lake Bokaren in Uppland where bodies of both humans and animals were deposited in waters at a presumed wetland 
platform (excavated together with Susanna Eklund \& Andreas Hennius in 20I5). The species selection shifted from humans in the Roman Iron Age, to horses during the Migration and Vendel periods. The sequence continued with the deposition of two humans at the end of the Vendel period (a skeleton determined as female) and the beginning of the Viking age (determined as male), where animal remains depositions continued into the early part of the medieval period. It is clear from the osteology that most humans and animals were deliberately killed (Fredengren 20I5; Fredengren \& Löfqvist 2019) and those who were produced for killing varied between species and genders in the course of the Iron Age, while the depositional place continued to attract depositions that stretched in time nearly over a millennium.

Relatedly, Bettina Stolle's (2020) study published in the previous volume of this journal, focuses on the butcher in the ritual killing of animals during the Late Iron Age and thus fills in important gaps how slaughter was formulated in the past. Stolle suggests that ritual killing was a multiplestage, collective process and that sacrifice was part of a culture of display. I would like to continue this conversation on butchery and add that such performances would have been conditioned on processes where certain others were made killable. Furthermore, I would also like to, in line with Haraway, draw attention to and give recognition the several other human and animal co-workers, that besides the butcher, contributed with bodily labour and also their lives to these deadly processes and displays - where some bodies were moved into death, for others to thrive.

Furthermore, we can also draw on Derrida's (2008) notion to ask what if the human or animal might not only have reacted to this, but also answered back? And further, what if the butcher responded to its killing as if it was a life of someone, not only something, or perhaps both. Possibly, in the butcher's repertoire may also lie a closing down of the senses, feelings and imaginings around the life of the othered other as it was made killable and ultimately deprived of its life. Besides the focus on the ritual specialist, these acts may have had repercussive effects that affected the level of violence in societies as well as hierarchization and othering. Hence, the study of human and animal ritual killing and sacrifice becomes a part of the study of the nature of the inhumane.

\section{Summoning the powers}

To apply Derrida's (2008), Despret's (2013) and Haraway's (2008) reasoning to archaeological analysis of so-called sacrificial places entails working from locations of both body and place. To understand more of the circumstances under which these depositions came about there is a need to trace 


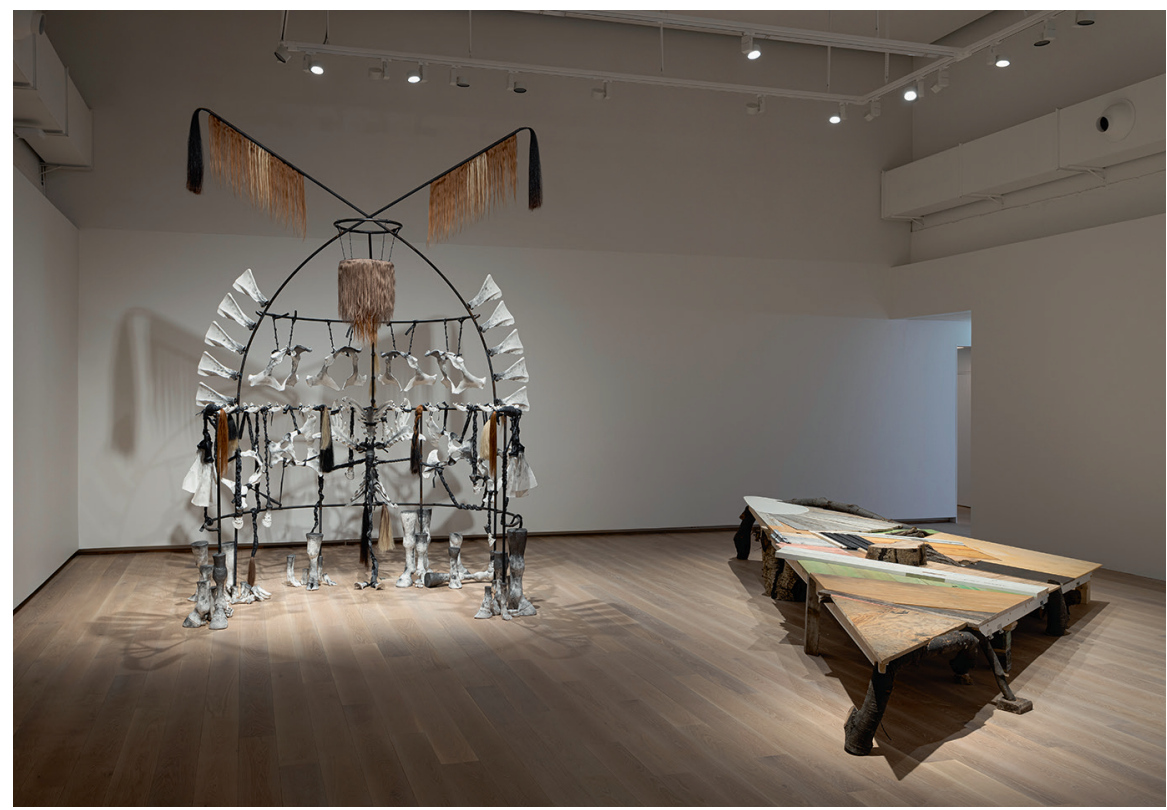

Figure I. Posthumous Dialogue by Signe Johannessen (detail). From the exhibition 'Experimentalfältet' at Accelerator, Stockholm University, 202I. Photo: Christian Saltas.

several different forces that produce them. Geology, water (Fredengren 20I5), fording points, the movement and labour of human/animal bodies, rocks, rock art contributed to how situated depositional spots came about and how they continued to work in the landscape - as places that attracted attention and repeated visits over time. This is what Despret (2013:37) might have called tracings of several 'rapports of forces' that were summoning and coinciding in these landscapes. In such processes of joint attunement - that make them more than assemblages of individual objects - several creatures, features and things come together with and make other living beings capable, affecting and being affected by such agencements or rapports of forces. However, those situated entanglements are not always of the benevolent kind for everyone involved. The case studies of the Water of the Times project have drawn attention to a number of forces at work in the making of depositional and even 'sacrificial' locations, such as Torresta, Uppåkra or Bokaren, where bones of both humans and hoofed animals were found - this enabled the tracing of several different, and situated processes, that may have contributed to the build-up of killability, killing, deposition and sacrifice in these locations.

Despret (2013:32) proposes that 'the historian should take the risk of speculating' in order both to understand what humans and animals offer to each other, and to get an insight into the experiences offered or forced 
upon them. Such speculative work also takes place in Signe Johannessen's artwork 'Posthumous Dialogue', currently being shown in 202I at the exhibition space at Accelerator, Stockholm University, which engages with a particular archaeological material and deals with questions around humananimal relations and wetlands. In the centre of the artwork is the find from Kvarntorp, at Högtorpsmossen in Närke, Sweden, where bone remains identified as the cranium of a middle-aged woman were found together with jaws of dog, shoulder bones from cattle, and ribs from an indeterminate species (possibly horse). A leg from a pig and a leg from a foal were also found. Together they make out a next to complete bodily assemblage of head, shoulder, ribs and legs and would have produced a hybrid creature of human and animal parts (Fredengren 2OII:I22-I23). The osteological analysis by Camilla Löfqvist shows that the human cranium has signs of cribra orbitalia, and the dog jaw has a healed fracture. The injury to the jaw was so severe that the dog would not have survived unless cared for by some other person during its recovery period. Whereas both the human and dog remains date to the Early Bronze Age, the radiocarbon dating of the other body parts were of much later dates.

Based on this find, 'Posthumous Dialogue' works to highlight the labour of both human and animal bodies that takes place in sacrifices made in wetland. Furthermore, this composed artistic research has folded out dialogues on how artwork and archaeological material revealed the exposedness of both animals and middle-aged women, but also on matters of multispecies care from the find of the dog jaw. It also started inquiries into how one could pay tribute to the lives and deaths of bodies that are packed and stacked in museum storages. Furthermore, the artwork explores how a multispecies hybrid body might work and move through work of the Cullberg dance company. Their performance work as a bodily speculative method that investigates what the situated bodily agentiality of more-than-human hybrid bodies would have been like. 'Posthumous Dialogue' also gives recognition of animal experiences of dominion and their dismemberment as bodies. This is made in relation to the fact that both the human and animal bodies at Kvarntorp were found in fragmented states. The artwork invites conversations on the use of human and animal bodies and their liveliness, as well the forces that pushed them to death. For me, collaborating in artistic research also opens for imaginings of what it would be like to be a somewhat disjointed, unabled/disabled or enabled othered creature, but one which has agency over several time-periods, as a temporal hybrid. What would it be like to do unruly work outside the bounds of ordinary species and temporal categories and on how to better practise multi-species care?

As we have seen, humans and animals are absorbed in each other's existences through ecologies that incessantly link across assumed boundaries 
between nature and culture. However, in such entangled webs there are complex, asymmetrical relations and power-plays that need to be teased out - and as I hope I have shown here - this can be done both affirmatively, creatively and critically.

\section{Multispecies archaeologies beyond entanglement}

Meanwhile the field of ethnography is under transformation from mainly human 'people-writing' into a multi-species exercise. Kirksey et al. (20I4:IO), for example, note that there is another root for ethnos that describes a swarm or gathering of groups. Multispecies studies thus work from critical non-anthropocentric perspectives that take an interest in the shared histories and interrelationships in communities of living beings that let 'diverse bodies of knowledge into conversation [...] pushing them in new directions' (Van Dooren et al. 20I6:2). Similar moves can and should be made in archaeology, where openings may lie in the tracing of a number of different affective gatherings that crisscross over the supposed boundary between humans and animals. Archaeology, with all the works mentioned above and (many others not mentioned) is already on the way towards a loosening up the boundary fencing of anthropocentrism to investigate, queer and query what happens when species meet.

Archaeology can on the one hand be understood as anthropocentric, if it is defined as studying material remains to understand mainly human activities (see Daniels 202I). However, on the other hand, archaeology is rarely only that and 'the human' is increasingly acknowledged as more-thanhuman. Many researchers, for example those that originate in posthumanist, critical animal studies, have engaged with and critiqued this anthropocentrism and opened up for other approaches in archaeology. In fact, the human or animal beings under study in archaeology are not autonomous bodily categories, but are co-produced with several other agential forces (Fredengren 20I3, 20I 8a). Bodies are both carrier bags and ecosystems that stretch through and further out from their containers. As evidenced in for example isotope analysis of a number of different more-than-human forces, such as food ecologies, landscapes, but also series of multispecies relationships, a lot of other factors make up the 'human' and 'animal' body. Such entangled relationships push the body to come into being and change. The human or the animal might not once and for all be stabilized, but rather, both may be on the move together with other bodily allies and foes. During certain times in prehistory such hybridity is attended to and cherished, while in other periods it may be a burden. In this keynote I have appreciated the relational and entangled approaches to multispecies archaeology, 
but also showed the need to take this reasoning further to ask questions about who and what benefits from a particular situated networked setup. I urge us to take one more step beyond entanglement and to highlight power structures that are diverse, time-specific and unequally affects the living conditions of human, less-than-human and animal lives, as some carry a heavier burden than others.

In future multispecies archaeology I would for example like to see and contribute to more work that:

- takes reasoning about situated bodily hybridities one step further: during what times does hybridity become commonplace? How does the interplay between different archaeological source materials act out and change over time? Given the situated hybridity of bodies, what may seem like 'ordinary' dogs or cattle may also fall out of their normalized ahistorical species category, particularly if their historically situated entanglements were considered. How will it then work to take modern animals as proxies for historically situated animals, as that to a degree silences out their specific temporal and situational entanglements? What is gained and what is lost, and what methods need to be applied for understanding deep time situated animal histories while tracing their gradual shift into becoming something else?

- explores human-animal relationships together with both scientists and artists, in what Kirksey et al. (20I6) call an application of collaborative tactics and methods to write the more-than-human into archaeological narratives. For example, this could be research that investigates how humans and animals are entangled in food webs and how they are coproduced in different ecological settings. In such archaeology, boundary and dualist-makings demand special attention, and so do meeting points between power, access to resources, technologies and habitats. What is of importance is to map particularly significant relations and to trace what sources and forces produce temporally and spatially situated phenomena and what makes change.

- explores the historical development of co-becomings/sympoesis contra autopoesis and care and repairwork. There are many ways of existing with animals, even tiny ones. One possibility is to trace the history of fertile soil, which comes together through work of for example worms and microbes, but needs care and hence often drags humans into long-term care relations, feeding the soil. An inspiration here is Maria Puig de la Bellacasa (20I7:24), who navigates away from both anthropomorphism and anthropocentrism to focus on distributed agencies and ecological 
care and how relations can be carefully reconfigured to build collaborative and respectful webs of co-existence, not only between humans and animals, but also with soils and microbes. To what extent can archaeology provide examples of multispecies care - that account for both exploitative and non-exploitative practices?

- engages further with archaeological studies that bear evidence on extinctions, such as those of mammoths (see Nyström et al. 20I0) as endlings - the last of their kind. Extinction studies are an important part of human-animal studies. Thom van Doreen (20I4:4) describes his engagement in this research as focusing on 'the webs of interaction in which living beings emerge, are held in the world, and eventually die. Life and death do not take place in isolation from others; they are thoroughly relational affairs for fleshy, mortal creatures'. For van Doreen (20I4:4-5), this lands in questions from 'What is lost when a species, an evolutionary lineage, a way of life, passes from the world? And 'What obligations do we have to hold open space in the world for other living beings?'. These questions are important both for discussing the entanglement of nature/ culture heritage, stewardship and conservation and for identifying where and when species loss occurred and the implications thereof.

- asks questions of how and under what circumstances archaeology can contribute to what Haraway (2008:3) names autre-mondialisation - a worldmaking that is less damaging than that of today. Archaeology in this context provides a range of source materials that can show multiple ways of living with animals - how history can inspire to other lifestyles and other ways of worlding the world. Such studies may also be of interest for how to unlearn unhelpful practices - identifying when the knots are tied in harmful ways - and to figure out where they may need to be re-tied in more respectful ways, as well as to highlight and acknowledge the importance of 'making with' others.This means investigating how the interrelationships between different beings were articulated elsewise; archaeology is often a confrontation with intense otherness. If we call this providing encounters with the amodern (Haraway 2004:70), a term used for breaking out of the bounds of present times and for striking conversation with a range of 'inappropriate/d others', or the pre-modern Armstrong Oma (2018:47) or something else, archaeological knowledge is important for giving insights into how to world the world differently. 


\section{References}

Ahlqvist, L. \& Vandkilde, H. 20I8. Hybrid Beasts of the Nordic Bronze Age. Danish Journal of Archaeology. Vol. 7(2) pp. I80-194.

Alaimo, S. 20Io. Bodily Natures: Science, Environment, and the Material Self. Indiana: Indiana University Press.

Alaimo, S. \& Hekman, S. 2008. Introduction: Emerging models of Materiality in Feminist Theory. In: Alaimo, S. \& Hekmans, S. (eds), Material Feminism, pp. I-I9. Bloomington: Indiana University Press.

Andersson, K. In press. Järnålderns djur. Stockholm: Carlssons Bokförlag.

Armstrong Oma, K. 20I8. The Sheep People: The Ontology of Making Lives. Sheffield: Equinox Publishing.

Armstrong Oma, K. 2020. On the Fringe: Sheepdogs and Their Status within Bronze Age Ontologies in Scandinavia. Current Swedish Archaeology. Vol. 28 pp. 99-I 20.

Armstrong Oma, K. \& Goldhahn, J. 2020. Introduction: Human-Animal Relationships from a Long-Term Perspective. Current Swedish Archaeology. Vol. 28 pp. I I-22.

Armstrong Oma, K. \& Hedeager, L. (eds). 20I0. Humans and Animals. World Archaeology. Vol. 42(2).

Arwidsson, G. 1942. Vendelstile, Email und Glas in 7.-8. Jahrhundert. Uppsala: Almquist \& Wiksells.

Barad, K. 2007. Meeting the Universe Halfways. Durham: Duke University Press.

Bergerbrant, S. 20I9. Wool Textiles in the Early Nordic Bronze Age: Local or Traded? In: Sabatini, S. \& Bergerbrant, S. (eds), The Textile Revolution in Bronze Age Europe: Production, Specialisation, Consumption, pp. 255-273. Cambridge: Cambridge University Press.

Boyd, B. 20I7. Archaeology and Human-Animal Relations: Thinking Through Anthropocentrism. Annual Review of Anthropology. Vol. 46 pp. 299-3I6.

Braidotti, R. 2013. The Posthuman. Cambridge: Polity Press.

Bintley, M.D.J \& Williams, T.J.T. (eds). 20I5. Representing Beasts in Early Medieval England and Scandinavia. Rochester: Boydell Press.

Brück, J. I999. Ritual and Rationality: Some Problems of Interpretation in European Archaeology. European Journal of Archaeology. Vol. 2(3) pp. 3I3-344.

Brück, J. 2004. Material Metaphors: The Relational Construction of Identity in Early Bronze Age Burials in Ireland and Britain. Journal of Social Archaeology. Vol. 4(3) pp. 307-333.

Conneller, C. 2004. Becoming Deer: Corporeal Transformatons at Star Carr. Archaeological Dialogues. II(I) pp. 37-56.

Costello, E. 2020. Transhumance and the Making of Ireland's Uplands, I550-I900. Woodbridge: Boydell Press.

Childe, V.G. [1928]I954. New Light on the Most Ancient East. London: Routledge \& K. Paul.

Der, L. \& Fernandini, F. 2016. Archaeology of Entanglement. Routledge: London.

Daniel, G.E. 202I. Archaeology. Encyclopedia Britannica. https://www.britannica.com/ science/archaeology. [Accessed 2I June 202I].

Derrida, J. 2008. The Animal that therefore I am. New York: Fordham University Press. 
Despret, V. 20I3. From Secret Agents to Interagency. History and Theory. Vol. 52 (December 2013) pp. 29-44.

Dobat, A.S., Price, T.D., Kveiborg, J., Ilkjær, J. \& Rowley-Conwy. P. 2015. The Four Horses of an Iron Age Apocalypse: War-horses from the Third-century Weapon Sacrifice at Illerup Aadal (Denmark). Antiquity. 88(339) pp. I9I-204.

Fahlander, F. 20I9. Fantastic Beings and Where to Make Them: Boats as Object-Beings in Bronze Age Rock Art. Current Swedish Archaeology. Vol. 27 pp. II9-2 I2.

Fjellström, M. 2020. Food Cultures in Sápmi: An Interdisciplinary Approach to the Study of the Heterogeneous Cultural Landscape of Northern Fennoscandia AD 600-I900. Theses and Papers in Scientific Archaeology 16. Stockholm: Stockholm University.

Fowler, C. \& Harris, O.J.T. 20I5. Enduring Relations: Exploring a Paradox of New Materialism. Journal of Material Culture. Vol. 20(2) pp. I27-I46.

Fredengren, C. 2002. Crannogs: A Study of People's Interactions with Lakes, with Particular Reference to Lough Gara in the North West of Ireland. Wordwell: Bray.

Fredengren, C. 2ог I. Where Wandering Water Gushes: The Depositional Landscape of the Mälaren Valley in Late Prehistoric Periods of Scandinavia. Journal of Wetland Archaeology. Vol. ıо pp. I09-I35.

Fredengren, C. 20I3. Posthumanism, the Transcorporeal and Biomolecular Archaeology. Current Swedish Archaeology. Vol. 2I pp. 53-7I.

Fredengren, C. 20I5. Water Politics: Wetland Deposition of Human and Animal Remains in Uppland, Sweden. Fornvännen. Vol. II I pp. I6I-I83.

Fredengren, C. 20I8a. Archaeological Posthumanities: Feminist Re-invention of Humanities, Science and Material Pasts. In: Braidotti, R. \& Åsberg, C. (eds), A Feminist Companion to the Posthumanities, pp. I29-I 40. New York: Springer.

Fredengren, C. 2018b. Becoming Bog Bodies Sacrifice and Politics of Exclusion, as Evidenced in the Deposition of Skeletal Remains in Wetlands near Uppåkra. Journal of Wetland Archaeology. I8(I) pp. I-I9.

Fredengren, C. 20I8c. Personhood of Waters: Depositions of Bodies and Things in Water Contexts as a Way of Observing Agential Relationships. Current Swedish Archaeology. Vol. 26 pp. 219-245.

Fredengren, C. In press. Worlding Waters with the Dead. Norwegian Archaeological Review.

Fredengren, C. Manuscript. Sacrifice and the Nature of the Inhuman: Depositions of Human and Animal Remains in Watery Places.

Fredengren, C. \& Löfqvist, C. 2015. Food for Thor: The Deposition of Human and Animal Remains in a Swedish Wetland Area. Journal of Wetland Archaeology. Vol. I5 pp. I 22-I 48 .

Fredengren, C \& Löfqvist, C. 20I9. Finitude: Human and Animal Sacrifices in a Norse Setting. In: Wikström af Edholm, K., Jackson Rova, P., Nordberg, A., Sundqvist, O. \& Zachrisson, T. (eds), Myth, Materiality and Lived Religions: In Merovingingan and Viking Scandinavia, pp. 225-262. Stockholm: Stockholm University Press.

Fudge, E. 2002. Perceiving Animals. Urbana \& Chicago: University of Illinois Press.

Fudge, E. 20I7. Thinking with Vinciane Despret. Humanimalia. Vol. 9(I) pp. I60-I72.

Gamble, C. I985. Early Man as Complex Hunter. Nature. Vol. 3I6(6028) pp. 485-486.

Giraud, E.H. 2019. What Comes After Entanglement? Activism, Anthropocentrism, and an Ethics of Exclusion. Durham and London: Duke University Press. 
Glykou, A., Lougas, L., Piliciauskiene, G., Schmölcke, U., Eriksson, G. \& Lidén, K. 202 I. Reconstructing the Ecological History of the Extinct Harp Seal Population of the Baltic Sea. Quaternary Science Reviews. Vol. 25I e. I0670I.

Goldhahn, J. 2019. Birds in the Bronze Age: A North European Perspective. Cambridge: Cambridge University Press.

Goldhahn, J. 2020. To Bring Back some Eagleness to Eagles: On Bird Worldings in the Bronze Age. Current Swedish Archaeology. Vol. 28 pp. 47-73.

Haraway, D.J. 2004. The Promises of Monsters: A Regenerative Politics for Innapropriate/d Others. In: Haraway, D.J (ed.), The Haraway Reader, pp. 295-336. London: Routledge.

Haraway, D. 2008. When Species Meet. Minnesota: University of Minnesota Press.

Haraway, D. 20I6. Staying with the Trouble: Making Kin in the Chthulucene. Durham and London: Duke University Press.

Harris, A. 2020. Palaeodiet and Infant Feeding in Coastal Arctic Settlements: Insights from Stable Isotope Analysis of Bone and Dentine Collagen and Amino Acids. Theses and Papers in Scientific Archaeology I8. Stockholm: Stockholm University.

Harris, O. \& Ciapolla, C. 20I7. Archaeological Theory in the New Millennium: Introducing Current Perspectives. London: Routledge.

Hedeager, L. 2004. Dyr og andre mennesker - mennesker og andre dyr: Dyreornamentikkens transcendentale realitet. In: Andren. A., Jennbert, K. \& Raudvere, C. (eds), Ordning mot kaos: Studier av nordisk förkristen kosmologi, pp. 219-287. Lund: Nordic Academic Press.

Hedeager, L. 20I0. Split Bodies in the Late Iron Age/Viking Age of Scandinavia. In: Rebay Salisbury, K., Sørensen, M.L.S. \& Hughes, J. (eds), Body Parts and Bodies Whole, pp. III-II 8. Oxford: Oxbow Books.

Hedeager, L. 20I I. Iron Age Myth and Materiality: An Archaeology of Scandinavia AD 400-I000. London \& New York: Routledge.

Hodder, I. 20I2. Entangled: An archaeology of the Relationships between Humans and Things. Oxford: Wiley-Blackwell.

Hodder, I. 20I6. Studies in Human-Thing Entanglement. www.ian-hodder.com/books/ studies-human-thing-entanglement. [Accessed 2I June 202I].

Jennbert, K. 20I4. Certain Humans, Certain Animals: Attitudes in the Long Term. In: Andersson Cederholm, E., Björck, A., Jennbert, K. \& Lönngren, A-S. (eds), Exploring the Animal Turn: Human-Animal Relations in Science, Society and Culture, pp. I83I92. Lund: Pufendorfinstitutet, Lunds universitet.

Jordan, P. 2004. Hunting, Fishing and Reindeer Herding Peoples of Siberia: Past, Present and future Challenges. General Anthropology. Vol. I I pp. I-9.

Jones, A.M. 20I5. Meeting Pasts Halfway: A Consideration of the Ontology of Material Evidence in Archaeology. In: Chapman, R. \& Wylie, A. (eds), Material Evidence: Learning from Archaeological Practice, pp. 324-338. London: Routledge.

Karlsson, J. 20I6. Spill. Om djur, hantverk och nätverk i Mälarområdet under vikingatid och medeltid. Stockholm: Stockholms universitet.

Kaliff, A. \& Oestigaard, T. 2020. The Great Indo-European Horse Sacrifice: 4000 Years of Cosmological Continuity from Sintashta and the Steppe to Scandinavian Skeid. Uppsala: Uppsala universitet.

Kirksey, E., Schuetze, C. \& Helmreich, S. 20I4. Introduction: Tactics of Multispecies Ethnography. In: Kirksey, E. (ed.), The Multispecies Salon, pp. I-24. Durham: Duke University Press. 
Kristoffersen, S. 20Io. Half Beast - Half Man: Hybrid Figures in Animal Art. World Archaeology. Vol. 42 pp. 26I-272.

Kveiborg, J., Ahlqvist, L. \& Vandkilde, H. 2020. Horses, Fish and Humans: Interspecies Relationships in the Nordic Bronze Age. Current Swedish Archaeology. Vol. 28 pp. 75-98.

Latour, B. 1993. We have never been Modern. Cambridge, MA: Harvard Univ. Press.

Lindström, T. 2020. Retrieving, Curating and Depositing Skulls at Pitted Ware Culture Sites. Current Swedish Archaeology. Vol. 28 pp. I47-I79.

Mannermaa, K. \& Kirkinen, T. 2020.Tracing the Materiality of Feathers in Stone Age North-Eastern Europe. Current Swedish Archaeology. Vol. 28 pp. 23-46.

Marshall, S. \& Alberti, B. 20I4. A Matter of Difference: Karen Barad, Ontology and Archaeological Bodies. Cambridge Archaeological Journal. Vol. 24(I) pp. 19-36.

Mbembe, A. 2003. Necropolitics. Public Culture. I5(I) pp. I I-40.

Merkelbach, R. \& Knight, G. (eds). 2020. Margins, Monsters, Deviants: Alterities in Old Norse Literature and Culture. Turnhout: Brepols.

Monikander, A. 20Iо. Våld och vatten: Våtmarkskult vid Skedemosse under järnåldern. Stockholm Studies in Archaeology 52.Stockholm: Stockholm universitet.

Nyström, V., Dalén, L., Varanyan, S. \& Lidén, K. 20Io. Temporal Genetic Change in the Last Remaining Population of Woolly Mammoth. Proceedings of the Royal Society of London. Biological Sciences. Vol. 277(I692) pp. 233I-2337.

Overton, N.J. \& Hamilakis, Y. 20I3. A Manifesto for a Social Zooarchaeology. Archaeological Dialogues. Vol. 20 pp. II I-I36.

Overton, N.J. \& Taylor, B. 20I8. Humans in the Environment: Plants, Animals and Landscapes in Mesolithic Britain and Ireland. Journal of World Prehistory. Vol. 3I pp. $385-402$.

Pedersen, E.A. \& Widgren, M. 20I I. Agriculture in Sweden, 800 BC-AD гоo०. In: Myrdal, J. \& Morell, M. (eds), The Agrarian History of Sweden. 4000 BC to AD 2000, pp. 467I. Lund: Nordic Academic Press.

Pilaar Birch, S.E. (ed.). 20I8. Multispecies Archaeology. London/New York: Routledge.

Pluskowski, A.G. 2007. Who ruled the Forests? An Inter-disciplinary Approach towards Medieval Hunting Landscapes. In: Hartmann, S. (ed.), Fauna and Flora in the Middle Ages, pp. 29I-323. Frankfurt: Peter Lang.

Puig de la Bellacasa, M. 20I7. Matters of Care: Speculative Ethics in More than Human Worlds. Minnesota: University of Minnesota Press.

Rose, D.B. 2or r. Wild Dog Dreaming: Love and Extinction. London: University of Virginia Press.

Storå, J., Ullén, I. \& Drenzel, L. 2020. Splitting Bodies: A Close-up Study of a South Swedish Bog Deposition from the Pre-Roman Iron Age. Journal of Archaeological Science: Reports. Vol. 34 e. I0262I.

Stolle, B. 2020. Ritual Slaughter through the Eyes of the Butcher: Perspectives on a Complex Practice. Current Swedish Archaeology. Vol. 28 pp. I8I-200.

Van Doreen, T. 20I4. Flight Ways: Life and Loss at the Edge of Extinction. New York: Columbia University Press.

Van Doreen, T., Kirksey, E. \& Muenster, U. 20I6. Multispecies Studies Cultivating Arts of Attentiveness. Environmental Humanities Journal. 8: (May 20I6) pp. I-23.

Wolfe, C. 2009. Human, All Too Human: 'Animal Studies' and the Humanities. PMLA. Vol. I24(2) pp. 564-575. 